\title{
COLLECTED WORKS OF ERASMUS
}

\author{
VOLUME 19
}


This page intentionally left blank 


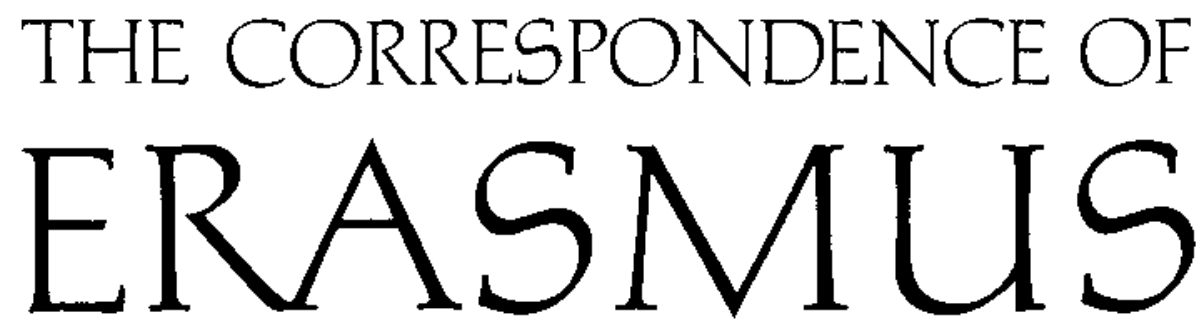

LETTERS 2635 TO 2802

April 1532-April 1533

translated by Clarence H. Miller $\uparrow$

with Charles Fantazzi

annotated by James M. Estes

University of Toronto Press

Toronto / Buffalo / London 
The research and publication costs of the Collected Works of Erasmus are supported by

University of Toronto Press

(C) University of Toronto Press 2019

Toronto / Buffalo / London

utorontopress.com

Printed in Canada

ISBN 978-1-4875-0458-8

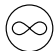

Printed on acid-free, $100 \%$ post-consumer recycled paper with vegetable-based inks.

\section{Library and Archives Canada Cataloguing in Publication}

Erasmus, Desiderius, -1536

[Works. English]

Collected works of Erasmus.

Includes bibliographical references and indexes.

Contents: v.19. The correspondence of Erasmus: Letters 2635 to 2802 ISBN 978-1-4875-0458-8 (v. 19: hardcover)

$$
\text { I. Title. }
$$

$$
\text { PA8500 } 1974 \quad 199^{\prime} .492 \quad \text { C740-06326x }
$$

University of Toronto Press acknowledges the financial assistance to its publishing program of the Canada Council for the Arts and the Ontario Arts Council, an agency of the Government of Ontario. 


\section{Collected Works of Erasmus}

The aim of the Collected Works of Erasmus

is to make available an accurate, readable English text

of Erasmus' correspondence and his

other principal writings. The edition is planned

and directed by an Editorial Board, an Executive Committee,

and an Advisory Committee.

EDITORIAL BOARD

William Barker, University of King's College

$\dagger$ Alexander Dalzell, University of Toronto

James M. Estes, University of Toronto, Chair

Riemer Faber, University of Waterloo

Charles Fantazzi, East Carolina University

James K. Farge, Pontifical Institute of Mediaeval Studies

John N. Grant, University of Toronto

Paul F. Grendler, University of Toronto

James K. McConica, Pontifical Institute of Mediaeval Studies, Chair Emeritus

John O'Malley, Georgetown University

Mechtilde O'Mara, University of Toronto

Hilmar M. Pabel, Simon Fraser University

Jane E. Phillips, University of Kentucky

Erika Rummel, University of Toronto

Robert D. Sider, Dickinson College

James D. Tracy, University of Minnesota

Mark Vessey, University of British Columbia

EXECUTIVE COMMITTEE

$\dagger$ Alexander Dalzell

James M. Estes, University of Toronto

Riemer Faber, University of Waterloo

Charles Fantazzi, East Carolina University

Lynn Fisher, University of Toronto Press

Paul F. Grendler, University of Toronto

James K. McConica, Pontifical Institute of Mediaeval Studies 
Jane E. Phillips, University of Kentucky

Suzanne Rancourt, University of Toronto Press, Chair

Robert D. Sider, Dickinson College

Mark Vessey, University of British Columbia

John Yates, University of Toronto Press

\section{ADVISORY COMMITTEE}

Jan Bloemendal, Conseil international ASD

Amy Nelson Burnett, University of Nebraska-Lincoln

H.J. de Jonge, Leiden University

Anthony Grafton, Princeton University

Ian W.F. Maclean, Oxford University

$\dagger$ Clarence H. Miller, Saint Louis University

J. Trapman, Conseil international ASD

Timothy J. Wengert, The Lutheran Theological Seminary at Philadelphia 